\title{
ANALISIS KELAYAKAN EKONOMI USAHATANI PADI SAWAH DI KECAMATAN PAMONA PUSELEMBA
}

\section{Economic Feasibility Analysis of Rice Field Farming at Pamona Puselemba District}

\author{
Marianne Reynelda Mamondol \\ Fakultas Pertanian Universitas Kristen Tentena \\ Jln. Torulemba No. 21 Tentena, Poso, Sulawesi Tengah \\ e-mail : mariannemamondol@gmail.com
}

\begin{abstract}
Abstrak
Penelitian ini bertujuan untuk mengetahui kelayakan ekonomi usahatani padi sawah di Kecamatan Pamona Puselemba. Indikator kelayakan ekonomi yang digunakan ialah pendapatan usahatani, $R / C$ Ratio, $\pi / C$ Ratio, BEP penerimaan, BEP produksi, BEP harga, dan batas aman penurunan harga produk. Pengumpulan data dilakukan dengan cara survey, meliputi observasi, wawancara, dan pengisian kuisioner. Sampel penelitian ditentukan melalui teknik purposif sampling. Data dianalisis dengan menggunakan analisis pendapatan, analisis $R / C$ Ratio, analisis $\pi / C$ Ratio, analisis $B E P$, dan analisis perubahan harga. Hasil penelitian menunjukkan bahwa usahatani padi sawah di Kecamatan Pamona Puselemba dengan luas tanam sebesar 1 ha pada umumnya memiliki kelayakan secara ekonomi. Rata-rata pendapatan usahatani ialah sebesar $R p$ 19.328.170/ha/MT, rata-rata nilai $R / C$ Ratio 2,62, rata-rata nilai $\pi / C$ Ratio $161,65 \%$, rata-rata BEP penerimaan $R p 4.473 .192,63$, rata-rata $B E P$ produksi $612,40 \mathrm{~kg}$, rata-rata BEP harga $\mathrm{Rp} 3.377,55 / \mathrm{kg}$, dan rata-rata batas aman penurunan harga beras sebesar 55,88 \%. Tingkat produksi, harga jual beras, dan efisiensi biaya produksi merupakan faktor-faktor yang mempengaruhi tingkat kelayakan ekonomi usahatani padi sawah. Produksi yang lebih besar, harga jual beras yang lebih tinggi, dan biaya produksi yang efisien akan meningkatkan kelayakan ekonomi usahatani.
\end{abstract}

Kata Kunci: pendapatan, $R / C$ Ratio, $\pi / C$ Ratio, BEP, batas aman penurunan harga

\section{Abstract}

The objective of this study is to find out the economic feasibility of rice field farmings in Pamona Puselemba District. Indicators of economic feasilibility encompass farming income, $R / C$ Ratio, $\pi / C$ Ratio, Revenue BEP, Production BEP, Price BEP, and safety limit for product price decreasing. Survey method is used in data collection, including observation, interview, and questionnaire filling. Research samples are determined with purposive sampling technique. Data is analyzed using the analyses of income, $R / C$ Ratio, $\pi / C$ Ratio, BEP, and price change. Result demonstrates that generally rice field farmings in Pamona Puselemba District with area of 1 ha have economic feasibility. The averages of income is $R p$ 19,328,170/ha/planting season, $R / C$ Ratio $2.62, \pi / C$ Ratio $161.65 \%$, revenue BEP $R p$ $4.473,192.63$, production BEP $612.40 \mathrm{~kg}$, price BEP Rp 3.377,55/kg, and safety limit for the decreasing 
price of rice is $55.88 \%$. The levels of production, selling price of rice, and cost production efficiency are factors that influence rice field farming economic feasibility. Higher production, rice selling price, and more efficient cost production will increase farming economic feasibility.

Keywords: income, $R / C$ Ratio, $\pi / C$ Ratio, BEP, safety limit for price decreasing

\section{PENDAHULUAN}

Keberlanjutan suatu usahatani sangat ditentukan oleh pengelolaan usahatani yang dilakukan oleh petani sebagai manajer. Manajemen usahatani adalah kemampuan petani untuk merencanakan, mengorganisir, menggerakkan, dan melakukan evaluasi terhadap pemanfaatan faktor-faktor produksi dengan sebaik-baiknya agar mampu memberikan produksi pertanian sebagaimana yang diharapkan (Suratiyah, 2008). Ukuran keberhasilan manajemen usahatani ialah produktivitas, baik produktivitas dari setiap faktor produksi maupun produktivitas dari usahatani itu sendiri. Karena itu diperlukan pengenalan petani secara utuh terhadap faktorfaktor produksi yang dimiliki dan yang dikuasai guna menjamin keberhasilan manajemen usahatani.

Manajemen usahatani yang baik akan menentukan kelayakan ekonomi usahatani. Dewasa ini sebagian besar usahatani telah bercorak komersil, di mana kegiatan usahatani lebih berorientasi pada pemasaran hasil-hasil usahatani. Orientasi pasar ini merupakan upaya petani selaku produsen untuk memperoleh pendapatan dari usahataninya. Dengan demikian, usahatani yang memiliki kelayakan ekonomi ialah usahatani yang memberikan keuntungan finansial bagi petani dan memiliki prospek keberlanjutan yang tinggi.

Kelayakan ekonomi usahatani berkaitan erat dengan masalah pengambilan keputusan manajemen, karena pengambilan keputusan secara tepat dalam pelaksanaan aktivitas usahatani akan meningkatkan kelayakan ekonomi usahatani tersebut (Suharyanto $d k k$, 2013). Harus diakui bahwa pengambilan keputusan yang menyangkut masalah produksi pertanian sangat dipengaruhi oleh faktor ketidakpastian (uncertainty), karena selain usahatani dipengaruhi oleh faktor-faktor yang dapat dikontrol (faktor internal), usahatani juga dipengaruhi oleh faktor-faktor di luar kontrol petani (faktor eksternal) (Prihtanti,
2014). Karenanya manajer usahatani dituntut untuk mengambil keputusan yang akurat dan cepat serta dapat diterapkan dengan segera. Keputusan yang diambil oleh petani umumnya terkait dengan hal-hal seperti tingkat produksi, harga produk, penggunaan input, maupun waktu untuk melakukan proses produksi (Kaparang, 2015).

Firdaus (2008) menyatakan bahwa pengambilan keputusan dalam usahatani didasarkan pada beberapa alat pengambil keputusan. Ada 2 tipe alat pengambilan keputusan, yaitu alat pengambilan keputusan non kuantitatif dan alat pengambilan keputusan kuantitatif. Alat pengambilan keputusan non kuantitatif ialah berupa intuisi, fakta, pengalaman, dan opini. Sedangkan alat pengambilan keputusan kuantitatif bagi manajer agribisnis maupun usahatani ialah beberapa metode perhitungan matematis yang sering digunakan untuk menilai kelayakan ekonomi suatu proses produksi.

Beberapa alat pengambilan keputusan kuantitatif yang juga berfungsi sebagai indikator kelayakan ekonomi ialah :

\section{1) Pendapatan atau keuntungan absolut}

Pendapatan atau yang disebut juga keuntungan absolut digunakan terutama bagi usaha atau bisnis yang ditujukan untuk mencari keuntungan absolut. Pendapatan atau keuntungan absolut adalah selisih antara penerimaan total dengan biaya produksi total. Secara matematis definisi ini dinyatakan dengan rumus :

$\pi=\mathrm{TR}-\mathrm{TC}$

di mana :

$\pi=$ pendapatan $/$ keuntungan absolut

$\mathrm{TR}=$ total revenue/penerimaan total

$\mathrm{TC}=$ total cost/biaya produksi total

Usaha atau bisnis dinyatakan layak (feasible) jika $\pi>0$. Jika $\pi<0$ usaha atau bisnis dinyatakan tidak layak, sedangkan jika $\pi=0$ usaha dinyatakan impas.

Perolehan pendapatan merupakan motivasi bagi petani untuk berusahatani guna 
memenuhi berbagai kebutuhan hidup (Roidah, 2015).

\section{2) $\mathrm{R} / \mathrm{C}$ Ratio (Revenue-Cost Ratio)}

$\mathrm{R} / \mathrm{C}$ Ratio merupakan rasio atau nisbah antara penerimaan total dan biaya produksi total yang secara matematis dinyatakan dengan rumus : $\mathrm{R} / \mathrm{C}$ Ratio $=\frac{\mathrm{TR}}{\mathrm{TC}}$

Usaha atau bisnis dinyatakan layak (feasible) jika R/C Ratio > 0. Jika R/C Ratio < 0 usaha atau bisnis dinyatakan tidak layak, sedangkan jika $\mathrm{R} / \mathrm{C}$ Ratio $=0$ usaha dinyatakan impas.

Semakin besar nilai R/C Ratio maka usaha atau bisnis akan semakin menguntungkan, sebab penerimaan yang diperoleh produsen dari setiap pengeluaran biaya produksi sebesar 1 unit akan semakin besar (Fitriadi dan Nurmalina, 2008).

\section{3) $\pi /$ C Ratio (Income-Cost Ratio)}

$\pi / \mathrm{C}$ Ratio merupakan rasio atau nisbah antara pendapatan atau keuntungan absolut dengan biaya produksi total. Secara matematis dinyatakan dengan rumus :

$$
\pi / \text { C Ratio } \quad=\frac{\pi}{\mathrm{TC}}
$$

Usaha atau bisnis dikatakan layak apabila nilai $\pi / \mathrm{C}$ Ratio > tingkat bunga bank yang berlaku. Nilai $\pi / C$ Ratio merupakan salah satu alat keputusan investasi, karena nilai $\pi / \mathrm{C}$ Ratio yang lebih besar daripada tingkat bunga bank yang berlaku menunjukkan bahwa adalah lebih menguntungkan jika pengusaha menginvestasikan dananya dalam kegiatan usaha dibandingkan menabung di bank (saving).

\section{4) Break Even Point (BEP) atau titik impas}

Break Even Point (BEP) atau titik impas adalah titik di mana pengusaha atau produsen tidak mengalami keuntungan ataupun kerugian. Titik impas digunakan untuk mempelajari hubungan antara penjualan, produksi, harga jual, biaya, dan rugi laba. Berdasarkan hubungan tersebut maka menurut Lumintang (2013) analisis BEP dapat digunakan untuk beberapa hal, yaitu :

a. Perencanaan laba (profit planning)

Melalui analisis titik impas dapat ditentukan volume usaha yang diperlukan guna menghasilkan tingkat laba tertentu yang merupakan bagian penting dari perencanaan laba.

b. Perubahan biaya

Dampak dari setiap perubahan biaya dapat diketahui dengan melakukan analisis BEP, di mana manajer dapat memproyeksikan berbagai hasil yang bisa diperoleh dari bermacam-macam alternatif sebelum mengambil keputusan akhir.

c. Perubahan harga

Perubahan harga, terutama penurunan harga dapat menyebabkan penurunan keuntungan yang diperoleh produsen atau pengusaha. Analisis BEP dapat digunakan sebagai salah satu acuan penentuan batas aman penurunan harga yang masih memberikan keuntungan bagi produsen.

d. Penentuan harga jual

Analisis BEP harga merupakan cara untuk menentukan harga pokok suatu produk. Perbandingan antara harga pokok dengan harga jual akan menentukan besaran keuntungan yang diperoleh produsen atau pengusaha. Analisis BEP terdiri atas 3 komponen, yaitu :

a. BEP Penerimaan, dinyatakan dengan rumus :

$\mathrm{BEP}$ Penerimaan $=\frac{\mathrm{FC}}{1-\frac{\mathrm{VC}}{\mathrm{TR}}}$

Keterangan :

$\mathrm{FC}=$ Biaya tetap

$\mathrm{VC}$ = Biaya variabel

b. BEP Produksi, dinyatakan dengan rumus

$\mathrm{BEP}$ Produksi $=\frac{\mathrm{FC}}{\mathrm{P}-\mathrm{AVC}}$

Keterangan :

$\mathrm{AVC}=$ Biaya variabel rata-rata

c. BEP harga, dinyatakan dengan rumus :

$\mathrm{BEP}$ Harga $=\frac{\mathrm{TC}}{\mathrm{Q}}$

Hasil analisis BEP akan menunjukkan tingkat penerimaan, produksi, dan harga di mana produsen atau pengusaha tidak mengalami keuntungan maupun kerugian.

\section{5) Perubahan harga}

Perubahan harga, terutama penurunan harga produk biasanya menimbulkan kekuatiran pada produsen akan penurunan jumlah keuntungan yang akan diperoleh. Analisis perubahan harga bertujuan membandingkan antara harga BEP dengan harga aktual. Perbandingan tersebut akan menentukan batas aman penurunan harga yang dapat ditolerir bagi produsen, di mana produsen masih dapat memperoleh keuntungan dan aktivitas usaha masih layak untuk dijalankan (Suratiyah, 2008). Faktor harga merupakan indikator ekonomi yang mampu mendorong petani untuk mengalokasikan sumberdaya yang dimiliki, dalam hal ini faktor-faktor produksi 
seoptimal mungkin untuk memperoleh keuntungan usahatani yang maksimum (Junaidi et al, 2014).

Kecamatan Pamona Puselemba merupakan salah satu wilayah yang dominan dengan penanaman padi sawah. Usahatani padi sawah telah menjadi mata pencarian utama bagi masyarakat yang bekerja sebagai petani, bahkan telah menjadi aktivitas yang diwariskan secara turun-temurun. Walaupun terdapat sebagian usahatani padi sawah yang dilakukan hanya untuk memenuhi kebutuhan konsumsi keluarga, tetapi terdapat pula usahatani padi sawah yang berorientasi pasar. Produksi yang dihasilkan sebagian dijual oleh petani guna memperoleh pendapatan untuk membiayai berbagai kebutuhan dalam keluarga petani. Karena itu perlu diteliti apakah usahatani padi sawah memiliki kelayakan ekonomi sebagai salah satu ukuran keberhasilan petani dalam melaksanakan manajemen atau pengelolaan terhadap usahatani.

\section{METODE PENELITIAN}

Penelitian ini dilaksanakan di Kecamatan Pamona Puselemba pada bulan September hingga November 2016. Pengumpulan data dilakukan melalui kegiatan survey, yang dilaksanakan dengan cara observasi, wawancara, dan pengisian kuisioner.

Penelitian dilakukan di 5 desa/kelurahan yang terdapat di Kecamatan Pamona Puselemba, yaitu Kelurahan Pamona, Desa Buyumpondoli, Desa Soe, Desa Mayakeli, dan Desa Tonusu. Sampel penelitian diambil sebanyak 1 orang petani dari setiap lokasi dengan menggunakan teknik sampling purposif. Kriteria yang ditentukan bagi sampel ialah lahan yang diolah merupakan milik sendiri, memiliki luas tanam 1 ha, menggunakan metode tanam padi secara konvensional (Tapin), dan tipe pengairan sawah tadah hujan. Dengan demikian diperoleh sampel penelitian sebanyak 5 orang petani.

Data yang dikumpulkan ialah data primer dengan sumber data ialah petani responden. Data primer yang dikumpulkan ialah : (a) Identitas responden, (b) Luas tanam, (c) Penerimaan petani dari produksi padi sawah, (c) Harga jual padi sawah, (d) Biaya pajak lahan, (e) Peralatan usahatani yang digunakan (jenis dan jumlah alat, harga pembelian), (f)
Penggunaan pupuk dan pestisida (kebutuhan dan biaya pembelian), (g) Penggunaan tenaga kerja (asal tenaga kerja, jumlah dan biaya tenaga kerja untuk berbagai kegiatan, dan (h) Biaya pembelian sak, sewa peralatan, angkutan gabah, serta sewa huller. Penerimaan dan biaya dihitung selama periode 1 musim tanam (MT).

Variabel-variabel yang digunakan dalam penelitian ini ialah : (a) Penerimaan total, yaitu penerimaan petani dari penjualan beras, (Rp/MT), (b) Penerimaan petani dari penjualan beras, yaitu produksi beras per MT dikalikan dengan harga jual beras per unit (Rp/MT), (c) Penerimaan petani dari penjualan dedak, yaitu produksi dedak per MT dikalikan dengan harga jual dedak per unit (Rp/MT), (d) Produksi beras, yaitu kuantitas beras yang dihasilkan pada saat panen $(\mathrm{kg} / \mathrm{ha})$, (e) Harga jual beras, yaitu harga penjualan beras per unit dari petani kepada pedagang $(\mathrm{Rp} / \mathrm{kg})$, (f) Produksi dedak, yaitu kuantitas dedak yang dihasilkan pada saat panen $(\mathrm{kg})$, (g) Harga jual dedak, yaitu harga penjualan dedak per unit dari petani kepada pedagang $(\mathrm{Rp} / \mathrm{kg})$, (h) Biaya produksi, yaitu jumlah seluruh biaya yang dikeluarkan oleh petani untuk usahatani padi sawah selama satu musim tanam (Rp/MT), dan (i) Pendapatan, yaitu selisih antara penerimaan total dengan biaya produksi (Rp/MT) Teknik analisis data yang digunakan dalam penelitian ini ialah :

1) Analisis pendapatan dengan rumus :

$$
\pi=\text { TR }- \text { TC }
$$

(Rahardja dan Manurung, 2006)

di mana :

$$
\begin{aligned}
\pi & =\mathrm{P} \cdot \mathrm{Q}-\mathrm{TC} \\
\pi & =\left(\mathrm{P}_{1} \cdot \mathrm{Q}_{1}+\mathrm{P}_{2} \cdot \mathrm{Q}_{2}\right)-\mathrm{TC}
\end{aligned}
$$

Keterangan :

$\pi=$ Pendapatan $(\mathrm{Rp} / \mathrm{ha} / \mathrm{MT})$

$\mathrm{TR}=$ Penerimaan total $(\mathrm{Rp} / \mathrm{ha} / \mathrm{MT})$

$\mathrm{TC}=$ Biaya produksi $(\mathrm{Rp} / \mathrm{ha} / \mathrm{MT})$

$\mathrm{P}_{1}=$ Harga jual beras $(\mathrm{Rp} / \mathrm{kg})$

$\mathrm{Q}_{1}=$ Produksi beras $(\mathrm{kg})$

$\mathrm{P}_{2}=$ Harga jual dedak (Rp/kg)

$\mathrm{Q}_{2}=$ Produksi dedak $(\mathrm{kg})$

2) Analisis R/C Ratio dengan rumus :

$\mathrm{R} / \mathrm{C}$ Ratio $=\frac{\mathrm{TR}}{\mathrm{TC}}$

(Suratiyah, 2008)

Ketentuan yang berlaku :

R/C Ratio < 1 : Usahatani merugi

$\mathrm{R} / \mathrm{C}$ Ratio $=1$ : Usahatani impas

R/C Ratio > 1 : Usahatani mengalami keuntungan 
3) Analisis $\pi / \mathrm{C}$ Ratio dengan rumus :

$\pi /$ C Ratio $=\frac{\pi}{\mathrm{TC}}$

(Suratiyah, 2008)

Ketentuan yang berlaku :

Jika $\pi /$ C Ratio > tingkat bunga yang berlaku maka usahatani memiliki kelayakan ekonomi.

4) Analisis Break Even Point (BEP), terdiri dari :

a. BEP Penerimaan dengan rumus :

BEP Penerimaan $=\frac{\mathrm{FC}}{1-\frac{\mathrm{VC}}{\mathrm{TR}}}$

Keterangan :

$\mathrm{FC}=$ Biaya tetap $(\mathrm{Rp} / \mathrm{MT})$

$\mathrm{VC}=$ Biaya variabel $(\mathrm{Rp} / \mathrm{MT})$

b. BEP Produksi dengan rumus :

BEP Produksi $=\frac{F C}{\mathrm{P}-\mathrm{AVC}}$

Keterangan :

$\mathrm{AVC}=$ Biaya variabel rata-rata
(Rp/MT)

c. BEP Harga dengan rumus :

BEP Harga $=\frac{T C}{Q}$

(Firdaus, 2008).

d. Analisis perubahan harga untuk menentukan batas aman penurunan harga, yaitu dengan membandingkan harga produk beras pada saat penelitian dengan harga produk beras pada saat BEP (Suratiyah, 2008).

\section{HASIL DAN PEMBAHASAN}

\section{1) Analisis Pendapatan}

Penerimaan total usahatani padi sawah yang merupakan penerimaan dari penjualan beras dan dedak ditunjukkan pada Tabel 1 dan Tabel 2 sebagai berikut.

Tabel 1. Produksi Beras dan Dedak

\begin{tabular}{cccrrr}
\hline \multirow{2}{*}{ Responden } & \multicolumn{3}{c}{ Produksi } & \multicolumn{2}{c}{ Harga } \\
\cline { 2 - 6 } & $\begin{array}{c}\text { Beras } \\
(\mathrm{kg})\end{array}$ & $\begin{array}{c}\text { Dedak } \\
(\mathrm{kg})\end{array}$ & $\begin{array}{c}\text { Beras } \\
(\mathrm{Rp} / \mathrm{kg})\end{array}$ & $\begin{array}{c}\text { Dedak } \\
(\mathrm{Rp} / \mathrm{kg})\end{array}$ \\
\hline $\mathrm{A}$ & & 5.320 & 665 & 8.000 & 4.000 \\
$\mathrm{~B}$ & & 3.500 & 1.125 & 7.600 & 1.353 \\
$\mathrm{C}$ & 4.020 & 1.508 & 7.600 & 4.250 \\
$\mathrm{D}$ & 3.000 & 750 & 7.600 & 2.400 \\
$\mathrm{E}$ & 3.000 & 400 & 7.500 & 2.500 \\
\hline
\end{tabular}

Tabel 2. Penerimaan Total Usahatani Padi Sawah

\begin{tabular}{ccrr}
\hline \multirow{2}{*}{ Responden } & \multicolumn{2}{c}{ Penerimaan Penjualan } & \multicolumn{2}{c}{$\begin{array}{c}\text { Penerimaan Total } \\
(\mathrm{Rp})\end{array}$} \\
\cline { 2 - 3 } & $\begin{array}{c}\text { Beras } \\
\text { (Rp) }\end{array}$ & $\begin{array}{c}\text { Dedak } \\
(\mathrm{Rp})\end{array}$ & 2.660 .000 \\
A & 42.560 .000 & 1.522 .125 & 28.220 .000 \\
B & 26.600 .000 & 6.409 .000 & 36.961 .000 \\
C & 30.552 .000 & 1.800 .000 & 24.600 .000 \\
D & 22.800 .000 & 1.000 .000 & 23.500 .000 \\
E & 22.500 .000 & & \\
\hline
\end{tabular}

Berdasarkan tabel dapat diketahui bahwa meskipun memiliki luas tanam yang sama yaitu sebesar 1 ha, terdapat perbedaan penerimaan total dari ke-5 responden penelitian yang disebabkan oleh perbedaan jumlah produksi beras dan dedak yang dihasilkan serta perbedaan harga jual produk. Perbedaan produksi disebabkan oleh adanya perbedaan teknik budidaya yang diterapkan oleh masing-masing petani. Perbedaan harga disebabkan oleh perbedaan pedagang yang membeli hasil produksi petani. Petani yang lokasinya lebih dekat ke pasar memperoleh harga yang lebih tinggi dibandingkan petani yang jauh dari pasar.

Biaya produksi total usahatani padi sawah terdiri atas biaya tetap (fixed cost) dan biaya variabel (variable cost). Jumlah biaya produksi yang dikeluarkan oleh responden penelitian ditunjukkan pada Tabel 3 sebagai berikut. 
Tabel 3. Biaya Produksi Total Usahatani Padi Sawah

\begin{tabular}{crrr}
\hline \multirow{2}{*}{ Responden } & \multicolumn{2}{c}{ Jenis Biaya } & \multicolumn{2}{c}{$\begin{array}{c}\text { Biaya Produksi Total } \\
(\mathrm{Rp})\end{array}$} \\
\cline { 2 - 3 } & $\begin{array}{c}\text { Biaya Tetap } \\
(\mathrm{Rp})\end{array}$ & $\begin{array}{c}\text { Biaya Variabel } \\
(\mathrm{Rp})\end{array}$ & 11.469 .900 \\
$\mathrm{~A}$ & 3.218 .400 & 8.251 .500 & 15.118 .000 \\
$\mathrm{~B}$ & 2.523 .000 & 12.595 .000 & 15.517 .600 \\
$\mathrm{C}$ & 2.994 .000 & 12.523 .600 & 10.241 .600 \\
$\mathrm{D}$ & 3.380 .600 & 6.861 .000 & 9.415 .075 \\
$\mathrm{E}$ & 3.468 .000 & 5.947 .075 & \\
\hline
\end{tabular}

Biaya tetap usahatani padi sawah terdiri dari pajak lahan, penyusutan alat dan mesin pertanian, dan upah tenaga kerja keluarga. Biaya variabel terdiri dari pembelian benih, pupuk, pestisida, karung, BBM, sewa gilingan, dan pemeliharaan mesin-mesin pertanian. Perbedaan jumlah biaya produksi yang dikeluarkan oleh setiap responden ditentukan oleh jenis kegiatan atau aktivitas usahatani yang dilakukan, tingkat produksi, dan pengelolaan usahatani oleh responden.

Biaya yang cukup signifikan besarnya ialah biaya pemupukan, karena dalam satu musim tanam petani melakukan beberapa kali pemupukan terhadap tanaman. Pupuk yang digunakan ialah pupuk kimia sintetik seperti Urea, SP 36, dan KCl. Kendala yang dihadapi ialah seringnya terjadi kelangkaan pupuk di pasaran dan harganya yang semakin meningkat, yang menyebabkan biaya pemupukan juga semakin besar.

Selain biaya pemupukan, biaya penggilingan gabah juga memiliki signifikansi dalam pengeluaran biaya produksi oleh petani. Sebenarnya petani tidak mengeluarkan uang tunai dalam pembayaran jasa gilingan, melainkan membayar dengan natura berupa beras hasil penggilingan. Hanya saja dalam perhitungan, beras yang diserahkan kepada pemilik gilingan dinilai dengan uang. Pembayaran jasa penggilingan dilakukan dengan sistem $10: 1$, artinya dari setiap $10 \mathrm{~kg}$ beras yang diperoleh maka $1 \mathrm{~kg}$ menjadi pembayaran bagi pemilik gilingan. Dengan demikian semakin besar produksi beras berarti pembayaran jasa penggilingan juga akan semakin besar.

Perbedaan biaya produksi juga disebabkan oleh faktor kepemilikan modal, terutama peralatan mesin pertanian. Petani yang memiliki mesin pengolah tanah (traktor) dapat menghemat biaya sewa traktor yang cukup tinggi. Demikian pula petani yang memiliki kendaraan sendiri untuk mengangkut hasil panen tidak perlu mengeluarkan biaya yang cukup besar untuk pengangkutan.

Pendapatan usahatani padi sawah pada masing-masing responden ditunjukkan pada Tabel 4 sebagai berikut.

Tabel 4. Pendapatan Usahatani Padi Sawah

\begin{tabular}{crrr} 
Responden & $\begin{array}{c}\text { Penerimaan Total } \\
(\mathrm{Rp})\end{array}$ & $\begin{array}{c}\text { Biaya Produksi Total } \\
(\mathrm{Rp})\end{array}$ & $\begin{array}{c}\text { Pendapatan } \\
(\mathrm{Rp})\end{array}$ \\
\hline A & 45.220 .000 & 11.469 .900 & 33.750 .000 \\
B & 28.122 .125 & 15.118 .000 & 13.004 .125 \\
C & 36.961 .000 & 15.517 .600 & 21.443 .400 \\
D & 24.600 .000 & 10.241 .600 & 14.358 .400 \\
E & 23.500 .000 & 9.415 .075 & 14.084 .925 \\
\hline Rerata & 31.680 .625 & 12.352 .435 & 19.328 .170 \\
\hline
\end{tabular}

Hasil analisis menunjukkan bahwa ratarata pendapatan usahatani ialah $\mathrm{Rp}$ 19.328.170/ha/ MT. Nilai pendapatan yang > 0 berarti berarti bahwa usahatani layak secara ekonomis.

\section{2) Analisis R/C Ratio}

Hasil analisis R/C Ratio usahatani padi sawah dapat dilihat pada Tabel 5. Nilai R/C Ratio menunjukkan jumlah penerimaan dari setiap 1 unit biaya yang dikeluarkan petani. Pada Tabel 5 dapat dilihat bahwa R/C Ratio usahatani padi sawah berkisar antara 1,86 
hingga 3,94. Secara keseluruhan usahatani padi sawah memiliki kelayakan secara ekonomi karena nilai R/C Ratio yang lebih besar daripada 1 . Walaupun demikian terdapat usahatani padi sawah yang memiliki keuntungan yang lebih besar daripada usahatani lainnya, karena semakin besar nilai $\mathrm{R} / \mathrm{C}$ Ratio berarti semakin besar penerimaan yang diperoleh dibandingkan biaya produksi yang dikeluarkan.

Tabel 5. Nilai R/C Ratio Usahatani Padi Sawah

\begin{tabular}{crrr} 
Responden & $\begin{array}{c}\text { Penerimaan Total } \\
(\mathrm{Rp})\end{array}$ & $\begin{array}{c}\text { Biaya Produksi Total } \\
(\mathrm{Rp})\end{array}$ & R/C Ratio \\
\hline A & 45.220 .000 & 11.469 .900 & 3,94 \\
B & 28.122 .125 & 15.118 .000 & 1,86 \\
C & 36.961 .000 & 15.517 .600 & 2,38 \\
D & 24.600 .000 & 10.241 .600 & 2,40 \\
E & 23.500 .000 & 9.415 .075 & 2,50 \\
\hline Rerata & & & 2,62 \\
\hline
\end{tabular}

\section{3) Analisis $\pi / \mathbf{C}$ Ratio}

Hasil analisis $\pi / \mathrm{C}$ Ratio usahatani padi sawah dapat dilihat pada Tabel 6 . Nilai $\pi / \mathrm{C}$ Ratio merupakan indikator produktivitas modal yang digunakan petani dalam proses produksi (Polakitan $d k k, 2015)$. Nilai $\pi / \mathrm{C}$ Ratio juga dapat menjadi faktor penentu keputusan petani untuk berproduksi, karena jika nilai $\pi / \mathrm{C}$ Ratio lebih besar jika dibandingkan dengan tingkat bunga bank yang berlaku maka akan lebih menguntungkan bagi petani untuk menginvestasikan dana yang dimilikinya dalam kegiatan usahatani. Adapun tingkat bunga bank yang berlaku pada saat penelitian ialah sebesar 8,85\%, lebih kecil daripada nilai $\pi / C$ Ratio dari kelima usahatani. Karena itu adalah lebih baik bagi petani untuk melakukan perputaran modal melalui investasi kegiatan usahatani dibandingkan menyimpan uang di bank (saving).

Tabel 6. Nilai $\pi / C$ Ratio Usahatani Padi Sawah

\begin{tabular}{crrr} 
Responden & $\begin{array}{c}\text { Pendapatan } \\
(\mathrm{Rp})\end{array}$ & $\begin{array}{c}\text { Biaya Produksi Total } \\
(\mathrm{Rp})\end{array}$ & \multicolumn{1}{r}{$\pi /$ C Ratio } \\
\hline A & 33.750 .000 & 11.469 .900 & $294,25 \%$ \\
B & 13.004 .125 & 15.118 .000 & $86,02 \%$ \\
C & 21.443 .400 & 15.517 .600 & $138,19 \%$ \\
D & 14.358 .400 & 10.241 .600 & $140,20 \%$ \\
E & 14.084 .925 & 9.415 .075 & $149,60 \%$ \\
\hline Rerata & & & $161,65 \%$ \\
\hline
\end{tabular}

\section{4) Analisis Break Even Point (BEP)}

Hasil analisis Break Even Point (BEP) untuk BEP penerimaan, BEP produksi, maupun BEP harga dapat dilihat pada Tabel 7. Hasil perhitungan nilai BEP (titik impas) untuk penerimaan, produksi, dan harga menunjukkan bahwa secara keseluruhan usahatani padi sawah telah memenuhi kelayakan ekonomi. Nilai BEP penerimaan, produksi, dan harga lebih besar dibandingkan nilai penerimaan, produksi, dan harga aktual pada saat penelitian dilakukan. Hanya saja yang perlu diperhatikan ialah responden yang memiliki tingkat pendapatan tertinggi (responden A) lebih cepat mencapai titik impas pada ketiga komponen dimaksud. Titik impas ialah titik di mana produsen tidak mengalami keuntungan maupun kerugian, dan sesudah titik impas maka produsen akan mengalami akumulasi pendapatan. Semakin cepat produsen mencapai titik impas, maka akumulasi pendapatan seiring dengan berjalannya waktu juga akan semakin besar (Swastika, 2004). 
Tabel 7. BEP Penerimaan, BEP Produksi, dan BEP Harga Usahatani Padi Sawah

\begin{tabular}{cccr}
\hline \multirow{2}{*}{ Responden } & \multicolumn{3}{c}{ BEP } \\
\cline { 2 - 4 } & $\begin{array}{c}\text { Penerimaan } \\
(\mathrm{Rp})\end{array}$ & $\begin{array}{c}\text { Produksi } \\
(\mathrm{kg})\end{array}$ & $\begin{array}{c}\text { Harga } \\
(\mathrm{Rp} / \mathrm{kg})\end{array}$ \\
\hline A & $3.934 .474,33$ & 499,06 & $2.156,00$ \\
B & $4.570 .652,17$ & 630,52 & $4.319,43$ \\
C & $4.529 .500,76$ & 667,61 & $3.860,10$ \\
D & $4.688 .765,60$ & 636,29 & $3.413,87$ \\
E & $4.642 .570,28$ & 628,53 & $3.138,36$ \\
\hline Rerata & $4.473 .192,63$ & 612,40 & $3.377,55$ \\
\hline
\end{tabular}

\section{5) Analisis Perubahan Harga}

Hasil analisis perubahan harga diperlihatkan pada Tabel $8 . \quad$ Tabel 8 menunjukkan batas aman penurunan harga beras yang dapat ditolerir bagi produsen. Selama penurunan harga tidak melampaui batas tersebut maka produsen masih tetap akan mengalami keuntungan dari usahataninya. Sebaliknya penurunan harga yang melewati batas aman akan menimbulkan kerugian bagi produsen.

Batas aman penurunan harga yang tertinggi diperoleh produsen yang memiliki perbandingan terkecil antara persentase harga BEP terhadap harga riil. Perbandingan ini sangat ditentukan oleh besarnya harga BEP yang juga merupakan harga pokok produksi. Harga pokok produksi yang semakin kecil mengindikasikan biaya produksi yang semakin kecil pula. Dengan demikian, produsen yang dapat memperkecil biaya produksi yang dikeluarkan selama proses produksi berlangsung akan memperoleh batas aman penurunan harga yang semakin besar.

Tabel 8. Batas Aman Penurunan Harga Beras pada Usahatani Padi Sawah

\begin{tabular}{ccc}
\hline Responden & $\begin{array}{c}\text { \% Harga BEP terhadap Harga Riil } \\
(\%)\end{array}$ & $\begin{array}{c}\text { Batas Aman Penurunan Harga Beras } \\
(\%)\end{array}$ \\
\hline A & 26,95 & 73,05 \\
B & 56,83 & 43,17 \\
C & 50,79 & 49,21 \\
D & 44,19 & 55,81 \\
E & 41,84 & 58,18 \\
\hline Rerata & 44,12 & 55,88 \\
\hline
\end{tabular}

\section{KESIMPULAN}

Usahatani padi sawah di Kecamatan Pamona Puselemba dengan luas tanam sebesar 1 ha pada umumnya memiliki kelayakan ekonomi yang ditunjukkan dari rata-rata pendapatan usahatani sebesar Rp 19.328.170/ha/MT, nilai R/C Ratio rata-rata sebesar 2,62, nilai $\pi / C$ Ratio rata-rata sebesar $161,65 \%$, nilai BEP penerimaan rata-rata sebesar Rp 4.473.192,63 , nilai BEP produksi rata-rata sebesar $612,40 \mathrm{~kg}$, dan nilai $\mathrm{BEP}$ harga rata-rata sebesar Rp 3.377,55/kg. Batas aman penurunan harga beras rata-rata sebesar $55,88 \%$. Walaupun demikian, kelayakan ekonomi juga ditentukan oleh tingkat produksi, harga beras, dan penggunaan biaya produksi oleh petani selaku produsen. Tingkat produksi yang lebih tinggi, harga beras yang lebih menguntungkan, dan biaya produksi yang semakin efisien menyebabkan tingkat kelayakan ekonomi yang semakin besar.

\section{UCAPAN TERIMA KASIH}

Terima kasih disampaikan kepada mahasiswa Fakultas Pertanian Universitas Kristen Tentena yang telah memberikan bantuan dalam pengumpulan data di lapangan, secara khusus kepada Meice Mbaresi, Greis Ganaga, Eko Linggupa, Ovel Tore, dan Rivaldy Suaran. 


\section{REFERENSI}

Firdaus, M., 2008. Manajemen Agribisnis. Bumi Aksara. Jakarta.

Fitriadi, F. dan R. Nurmalina, 2008. Analisis Pendapatan dan Pemasaran Padi Organik Metode System of Rice Intensification (SRI) : Kasus di Desa Sukagalih, Kecamatan Sukaratu, Kabupaten Tasikmalaya). Jurnal Pengkajian dan Pengembangan Teknologi Pertanian. 11 (1) : $94-103$.

Junaidi, Zamzami, dan E. Achmad, 2014. Analisis Produksi, Distribusi Pendapatan Petani dan Dampak Program Optimalisasi Lahan Terhadap Produksi Padi Sawah di Kabupaten Muaro Jambi. Jurnal Perspektif Pembiayaan dan Pembangunan Daerah. $2(1): 51-61$.

Kaparang, G., 2015. Kajian Usahatani Padi Sawah di Kelurahan Taratara Satu Kota Tomohon. Jurnal Cocos. 6 (6) : 1 - 12.

Lumintang, F.M., 2013. Analisis Pendapatan Petani Padi di Desa Teep Kecamatan Langowan Timur. Jurnal EMBA. 1 (3) : $991-998$.

Polakitan, D., A.Dp. Mirah, F.H. Elly, dan V.V.J.Panelewen, 2015. Keuntungan Usahatani Padi Sawah dan Ternak Itik di
Pesisir Danau Tondano Kabupaten Minahasa. Jurnal Zootek. 35 (2) : 361 367.

Prihtanti, T.M., 2014. Analisis Risiko Berbagai Luas Pengusahaan Lahan pada Usahatani Padi Organik dan Konvensional. Jurnal Agric. 26 (1) : 29 - 36.

Rahardja, P. dan M.Manurung, 2006. Teori Ekonomi Mikro : Suatu Pengantar. Lembaga Penerbit Fakultas Ekonomi UI. Jakarta.

Roidah, I.S., 2015. Analisis Pendapatan Usahatani Padi Musim Hujan dan Musim Kemarau (Studi Kasus Desa Sepatan Kecamatan Gondang Kabupaten Tulungagung). Jurnal Agribisnis Fakultas Pertanian Unita. 11 (13) : 45 - 55.

Suharyanto, J.H.Mulyo, D.H.Darwanto, dan S. Widodo, 2013. Analisis Efisiensi Teknis Pengelolaan Tanaman Terpadu (PTT) Padi Sawah di Provinsi Bali. Jurnal SEPA. 9 (2) : $219-230$.

Suratiyah, K., 2008. Ilmu Usahatani. Penebar Swadaya. Jakarta.

Swastika, D.K.S., 2004. Beberapa Teknik Analisis dalam Penelitian dan Pengkajian Teknologi Pertanian. Jurnal Pengkajian dan Pengembangan Teknologi Pertanian. 7 (1) : $90-103$. 
Jurnal Envira Volume 2 Nomor 1 Desember 2016 